Case for Teaching

\title{
Holy House or New Blood? Tink's Succession Case
}

\author{
Santo de Casa ou Sangue Novo? Caso de Sucessão da Tink
}

\author{
Eleandra Maria Prigol Meneghini ${ }^{1} \odot$ \\ Ana Paula Pereira dos Passos' 10 \\ Sidnei Vieira Marinho' ${ }^{\circ}$ \\ Anete Alberton ${ }^{10}$
}

\section{INTRODUCTION}

Thursday, April 2018, it was raining that autumn afternoon in Panambi, Rio Grande do Sul. While Pedro Bazzi, one of the founders and CEO of the family company Tink, savored his coffee, he reread the report he had received from Antônia Frigo, with an interviews' summary conducted with Tink's partners on the succession process.

Antônia was a partner and the daughter of one of the founding partners. She asked for permission to develop a study on the company's succession - a topic commented on by Pedro in one of the meetings with partners. Pedro had the goal of leaving Tink in two years and liked Antônia's idea of listening individually to all the partners since it could bring new information.
Tink was made up of seven family groups and met every third Thursday of the month to hold the ordinary meeting. It always happened after work hours, and, for Pedro, more than just passing on information, it was a way of maintaining the group's union and solidifying the company's culture, which, in its 20 years of existence, had never had any disagreement between its partners.

The regular meeting had been implemented since the founding of Tink. On that occasion, the birthdays of the members of the month were celebrated. Even if there was no birthday boy or girl, there was always food and drinks.

\footnotetext{
1. Universidade do Vale do Itajaí, Programa de Pós-Graduação em Administração, Itajaí, SC, Brazil.

\begin{tabular}{|c|c|c|c|c|c|c|c|c|c|}
\hline & 1 & 2 & 3 & 4 & 5 & 6 & 7 & 8 & 9 \\
\hline $1^{\text {st }}$ round & $\stackrel{8}{2}$ & (x) & $\stackrel{9}{2}$ & x & & & & & \\
\hline $2^{\text {nd }}$ round & 0 & 2 & & & & & & & \\
\hline $3^{\text {rd }}$ round & $\frac{6}{2}$ & & & & & & & & \\
\hline $4^{\text {th }}$ round & $\stackrel{9}{2}$ & & & & & & & & \\
\hline
\end{tabular}

JEL Code: A20, M14, L26.

Editor-in-chief: Wesley Mendes-Da-Silva (Fundação Getulio Vargas, EAESP, Brazil) [] Associate Editor: Paula C. P. de S. Chimenti (Universidade Federal do Rio de Janeiro, COPPEAD, Brazil) (1) Reviewers: Two of the reviewers chose not to disclose their identities. Peer Review Report: The disclosure of the Peer Review Report was not authorized by its reviewers. Received: February 25, 2019 Last version received: October 15, 2020 Accepted: December 07, 2020 
Four managers, all partners, managed Tink. Pedro Bazzi was the CEO, Jorge Santos was the financial and administrative director, Fausto Lins, the commercial director, and Jean Gonçalves, the production director. Decisions were centralized, and in every ordinary meeting, each director was responsible for presenting the indicators for his area, and Pedro made the necessary notes on the results. The meeting always took place in a cordial atmosphere, and rarely did partners who did not work at the company asked questions. Relationships between partners and between managers and employees contained paternalistic aspects and were organized hierarchically.

The clock's hands were approaching 6:30 pm that Thursday and Tink's partners were starting to arrive for yet another regular meeting. Pedro then closed the report folder, which he had received from Antônia, on the succession process. He felt prepared for a different meeting that day.

Nevertheless, would Tink be prepared to make decisions as severe as the succession? Would the partners be able to reach an agreement? What is the best decision to be made: internal succession, a Tink manager, or external, with a market professional?

\section{YELLOW, THE COLOR OF THE NEW}

Pedro Bazzi was from a rural family, born in the interior of Santa Catarina. He attended high school in agricultural schools. At the age of 17, he was classified in the entrance exam of the University of São Paulo (USP) in the Agronomy course, concluded in 1981, when he then searched for professional experience. Pedro passed a test to work in rural extension in Rio Grande do Sul, in the small town of Panambi, where he was responsible for supporting the management of family agriculture through a public institution. Its primary duties were to guide and organize producers regarding managing their properties, always seeking to improve results.

In 1988, for personal reasons, he resigned and started his career as an entrepreneur. Taking advantage of the expansion of a large agribusiness installed in the region, Pedro set up a representation of agricultural implements, through which he sold and assembled equipment.

In 1997, he became interested in the paint industry for sale in the neighboring city. After visiting the precarious facilities, he saw a future in the business and invited four acquaintances to the company who had resources to be invested: Eron Frigo, Lucio Brunatto, Alessandro Gonçalves, and Joáo Alencar. Specifically, Eron Frigo had sold his rural property and moved to the city. He worked with Pedro on assembling equipment and invested his capital in banking applications. Lucio Brunatto had sold his share in a society that no longer interested him. However, he wanted to continue to undertake. Alessandro Gonçalves was Pedro's colleague in the rural extension and had already confided to him his desire to undertake. João Alencar was a robust rural producer, a client of Pedro's, and, like Alessandro, he was interested in investing his resources in investments, in addition to banking.

Pedro introduced his colleagues to the idea of investing in the paint industry. Everyone had known each other for a long time, and, above all, they knew Pedro's suitability and entrepreneurship. They trusted his ideas and agreed to invest in the business. Thus, the story of Tink began.

\section{GREEN, THE COLOR OF GROWTH}

In September 1998, the five partners decided to transfer the acquired paint industry, which was installed in a neighboring city, to Panambi, the city where they lived and where they saw the company's growth. Thus, Tink's operation began at the new address, and four employees who worked there before the purchase moved their residence to Panambi, among them, Fausto Lins. Pedro was the legal responsible for the company and a majority partner. However, he did not exercise direct activity, and he only guided the management work of partner Lucio Brunatto and employee Fausto Lins, who worked directly in the company's daily life.

At the beginning of Tink's activities, the space was relatively small, the activities were manual, and the quality of the products sold - industrial paint and furniture was not so good. The sales volume was low, the partners were unaware of the business and had the know-how of former employees and the responsible chemical engineer's help, who supported them from a distance.

A change in focus marked the first years. In 2000, the company migrated to the residential paint segment, motivated by the difficulties that the furniture industries were experiencing. In 2002, it opened a paint resale shop, intending to consolidate a point of sale directly to the consumer. On that occasion, the partner Lucio Brunatto took over the store and, to replace him, a first management contract was made. Jorge Santos, a boy with a degree in accounting and experience in local offices, was hired to work with Fausto Lins in charge of the company.

Pedro and the other partners participated in Tink's routine sporadically, as demand demanded. The objective was to pay the investment made with the lowest possible cost. Therefore, management expenses were avoided.

In 2004, for fear of losing the employees Jorge and Fausto to the competition, Pedro and the other partners 
invited them to join the partnership. At that moment, Tink's social contract was created, defining clauses for the purchase and sale of shares. The minimum percentage for acquisition by a new member was set at $2 \%$, and it was defined that the candidate would need to be accepted by $100 \%$ of current members, except for the transfer between first-degree relatives who, in the opinion of the members of Tink, would have no restrictions on their approval. Fausto became a partner in the same year, and Jorge, in 2005. In 2006, partner João Alencar transferred part of his capital at Tink to his son Marcos, since he had a degree in Administration and would accompany business on behalf of the family.

In 2007, Jean Gonçalves, son of partner Alessandro, was hired. Jean had started his degree in Business, and this was his first job. He started in a productive area as a production assistant. He was the first heir to join Tink's staff. In 2009, with the end of the agribusiness expansion, Pedro ended his activities with the representation of agricultural implements. Tink, on the other hand, continued to grow and required more regular supervision. Thus, Pedro introduced himself to take over the company's management, which was fully accepted by the partners.

Thus, from 2009, Pedro became the CEO of Tink. Since then, he has focused on organizing the company and analyzing how to maximize earnings, reduce complaints, and continue to seek an excellent product. New practices have been employed to reduce the rate of complaints related to delivery. In 2010, for example, the company invested in its vehicle fleet to transport products. In the same year, Pedro consolidated Tink's management structure. When Fausto took over the sales team, Jorge became officially responsible for the financial and administrative area, and Jean, for the production area. Due to his promotion, Jean's father transferred $2 \%$ of his shares, making him a partner.

In the following years, Tink was adapting, acquiring equipment, and improving its structure. In all, ten expansions were carried out in the industrial park. The company won partners and sought external knowledge through fairs and with suppliers. Growth was around $20 \%$ per year. Until, in mid-2015, impacted by the financial crisis, it saw its growth stagnate.

Pedro, however, was unmoved. When comparing Tink with its competitors, in his view, it was in an ideal financial situation, had no debts, had low defaults, and maintained the culture of reinvesting part of the profit. Decisions related to the financial area - investment, financing, and profit allocation - were conservative.

Over the years, Pedro sold part of his shares to Fausto and Jorge. Partner Marcos Alencar also acquired shares from Pedro on two occasions, and, in other situations, Tink acquired these shares for sale, redistributing them to all partners, thus changing their ownership percentages. In 2016 and 2017, Pedro made new sales to the sons of partner Eron Frigo, Antônia, and Bruno, respectively (Appendix 1). Pedro had two daughters, who became professionals residing in another state. At family gatherings, they suggested to sell their shares and move in with his wife to the city where they lived. They had no plans to return to their hometown and wanted to have their relatives closer.

Tink reached 2018 with 52 direct employees and 23 sales representatives. The company served the three southern states, covering 375 cities, with 988 active customers, and had a complete mix for the real estate line, in addition to products aimed at the industrial line, a branch that the company was gradually resuming. There was also a concern with regulation, innovation, and market trends. To this end, the company maintained a partnership with the Engineering courses of educational institutions in the region to develop its products and had the seal of conformity of the Brazilian Association of Technical Standards (ABNT).

\section{BLACK, THE COLOR OF REFLECTION}

In 2018, Pedro began to hear his daughters and wife's appeals and planned to leave the company in two years. As he read the report on the succession process, which Antônia had prepared for him from the interviews, he reflected: he was 60, retired, his two daughters followed their professions and started a family in another state, and his wife reminded him of the real priorities for more quality of life, leisure, and health.

On the other hand, because he was the creator of that business, Pedro maintained a bond with Tink that left him in doubt. He wanted to leave the company transparently. He believed that the team would have the conditions and skills to continue the company and that, despite the different profiles, the group lived the family culture and would continue to act together, even maintaining the conservative model and growing through its resources.

Four professionals formed the company's management team: Pedro, Jorge, Fausto, and Jean participated in the management. All were partners and made decisions for the company's continuity in a centralized manner, each in a different role. In every ordinary meeting, they presented the indicators of their areas to the other non-managing partners, and Pedro made the necessary notes on the results.

Pedro opened his desk drawer and removed the folder with these managing partners' resumes, which he had been analyzing for a few days. The first was Fausto Lins, 50 years old, commercial director, and graduated in Pedagogy, who worked at the company even before the new partners bought it. Fausto worked with the external public, visited 
and prospect clients. He was responsible for the company's 37 sales representatives. Given Fausto's curriculum, Pedro reflected: "Fausto has good personal relationships with the team. However, he has difficulties doing good business."

The second curriculum was Jorge Santos, 37 years old, the company's financial and administrative director. With a degree in Accounting and specialist in Financial Management, Jorge had previous experience with Tink, in accounting offices. In Pedro's view, he had a technical profile, showed good accountant characteristics, was focused, demanding results, and was consistent and secure. However, he had difficulties with interpersonal relationships.

The third curriculum was that of Jean Gonçalves, 28 years old, production director, graduated in Administration and specialist in Production Engineering and Industrial Management. He joined Tink as a production assistant in 2007 when he started college. It was his first job and, little by little, he grew up. Pedro smiled when he remembered how Jean was demanding, subtle in details, seeking innovation, always confident, but with difficulties in dealing with unforeseen circumstances and making improvements. His countenance became more serious when he remembered some comments of partners who considered him an unknown figure, as he was political in his dealings and did not express what he thought and desired.

After analyzing the resumes, Pedro closed the folder and sighed. He believed that the internal succession, by one of the three managing partners, would ensure continuity in the company's management, maintaining the particularities of the values shared between the family and the hierarchical relationship existing between the partners, managers, and employees. The external succession, on the other hand, would bring new scenarios. However, for him, the group's decision would be based on understanding how Tink's management was doing. Either way, the partners would need to decide which way to go, and he would then go his way.

\section{RED, THE COLOR OF CONFLICT}

The result of the interviews reinforced, for Pedro, what he always tried to pass on to the partners: trust. In the interviews, the partners were unanimous as to their suitability and integrity. Everyone knew that Pedro wanted the best for Tink. However, from the interviews made by Antônia, Pedro became aware of information about his management and his personality that he was uninformed of, such as discontent, on the part of some non-managing partners, for not feeling heard when expressing opinions. In the partners' speeches, everyone's insecurity about his departure and about the financial crisis that had stagnated Tink's growth in the last two years also transpired.
The interviews presented controversial opinions from the partners on how to carry out the succession process. On the one hand, a part of the partners, mainly those who did not work in the company, defended external succession, as they did not identify, in the current team, the profile apt to occupy Pedro's chair. They supported the idea of professionalizing management in order to separate family relationships from professional decisions at Tink, as stated by partner Marcos Alencar:

This lack of definition today does not give me the confidence to increase the invested capital. I believe that someone from outside is the best way out for Tink. In my opinion, the current managing partners do not have the appropriate profile, nor do they have the necessary skills. I think we have to strengthen the group, and we cannot miss the chance to professionalize the company with Pedro's departure.

Besides, these partners saw a high risk of creating a severe problem in the company in the internal succession because, if the chosen one did not meet expectations, dismissing him would hinder the subsequent coexistence between the partners. The group saw, in the external succession, gains for the company. For them, a professional in the market would bring Tink's internal professionals' experience. In this sense, Eron Frigo, one of the founding partners, questioned:

If we bring in someone from outside, with a market vision and experience in managing chemical industries, we can make gains that we do not even see today, not to mention that we avoid possible internal problems. For example, if we hire someone from the market and there is no the harmony that we expect, we can disconnect this manager and move to a previously planned background, but if we promote one of the managing partners and it does not work, what do we do with that person?

The group that defended the internal succession was made up of managing partners, and their families bet mainly on maintaining the company's culture, which, for them, would be put at risk by a market professional. The group believed that someone inside, who already worked at Tink, would continue the current management without making extreme changes. They defended the family culture and wanted the company to continue to be managed by one of the partners. However, there was no consensus as to the name of the successor and the possible candidates interviewed. Alessandro Gonçalves, the founding partner, commented:

The best option is internal succession by managing partners. External succession is not a viable option, as the future manager needs to be a person who knows 
Tink, who has a connection with the current culture. An outsider may not adapt to the company. The successor could be one of the sixteen partners, but preferably one of the managing partners who already live its day-to-day activities.

Also, part of this group defended rotating succession, in which each manager would occupy the chair of the presidency for a pre-defined period, and part understood that the chair did not need to be occupied. Each manager could answer for his area and report to the partners, represented by a commission. As Jorge, managing partner, understood:

The vacancy would not necessarily need to be filled, they could continue the company's work without a president. They could have a committee with three or four partners, make the most critical decisions themselves.

In the case of internal succession, when asked about the potential of the managing partners to occupy Pedro's position, the partners showed insecurity for the most part. They understood that none of them were prepared to assume the position with the necessary skills for a good manager and expressed their concern with carrying out a professional evaluation of the candidates before making the decision.

Regarding Pedro's management, some partners expressed non-conformity, mainly because their ideas were not accepted. They admitted that they no longer expressed their opinions because they knew that the CEO would not endorse them. It was also noticed by Jean, one of the current managing partners, who stated that the ideas of the partners who did not work in the company did not have the same weight as the ideas of the managing partners:

At meetings, members try to be participatory, but the suggestions presented, most of the time, are not applied, and previous discussions are not resumed. There is excellent autonomy in the decisionmaking of the CEO, and the participation of the external partner is not active. The external partners' suggestions do not have the same weight as that of the managing partners. It is necessary to reduce the personalism that still exists, which needs to be replaced by professionalism.

In some partners' perception, the lack of rationality and the excessive emotional bond made management inefficient. Many employees were hired due to affective relationships when there was a need for people with technical knowledge and experience to reduce costs, increase productivity, and maximize results.

\section{GRAY, THE COLOR OF DECISION}

On Thursday, at 6:30 pm, Tink's partners started arriving for yet another regular meeting. Pedro closed the folder of the report received from Antônia on the succession process and prepared to have a different meeting. All members would come to the meeting with the perspective that they would talk about the topic covered in the interviews. In this way, they would have the opportunity to speak openly about what they thought and what they wanted for the company's future. They could expose their fears and insecurities, praise, and improvements that they deemed necessary. In addition to the presentations of the monthly indicators by Tink's directors, Pedro needed to conduct this conversation with prowess.

Nevertheless, Pedro knew that his doubts also reached the other partners. After all, what is the best decision to be made? Should they carry out internal or external succession? Would it be better to choose one of the managing partners or the extinction of the position in the internal succession? In the external succession, would a market manager with knowledge about the segment bring benefits to Tink? Would the company's culture be at risk with the external succession? Would Tink be prepared for this succession process? There were many doubts and challenges about the future management of Tink. 


\section{APPENDIX 1}

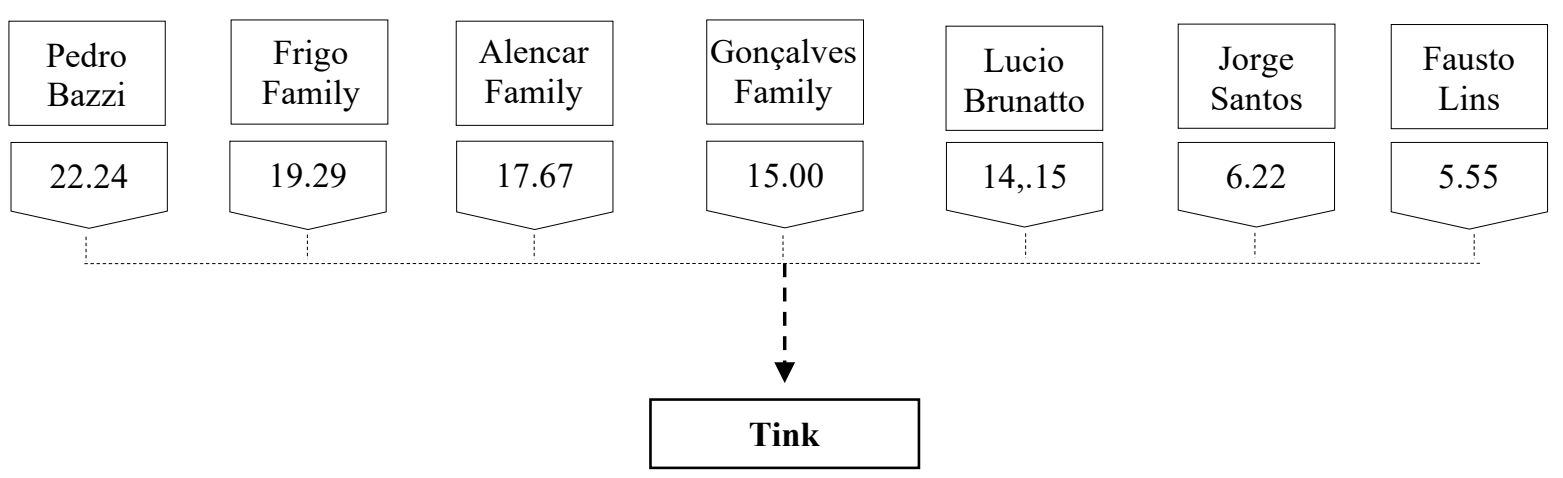

Figure A1. Shareholding structure of Tink (in \%).

Source: Elaborated by the authors. 


\section{ABSTRACT}

This teaching case aims to promote a reflection on the succession process of Tink, a family paint industry, composed of seven family nuclei, located in the municipality of Panambi, state of Rio Grande do Sul. In 2018, the company had been on the market for two decades, and Pedro, the CEO since 2009, informed the partners that he would leave the management in a period of two years. The managing partners defended internal succession and bet mainly on maintaining the company's culture. The partners that did not work in the company, on the other hand, defended external succession, since they did not identify, in the current team, the profile apt to occupy Pedro's chair. Thus, it was necessary to discuss the possibilities of succession, considering the divergent positioning of the partners. For this case, it is proposed that students put themselves in Pedro's place, in order to provide them with a debate about the advantages and disadvantages of internal and external succession for Tink. It is proposed that the case be used in undergraduate and graduate lato sensu courses in the field of Management, in disciplines of Organizational Strategies and People Management that focus on succession in family businesses, management skills, and the maintenance of culture.

Keywords: succession; family businesses; management competencies; maintenance of culture; teaching case.

\section{LEARNING OBJECTIVES}

This case was developed for application in undergraduate and graduate lato sensu courses in the field of Management, in disciplines of Organizational Strategies and People Management, in sessions that address the concepts related to succession in family businesses, management skills, and culture maintenance. Through the case, it is expected that the student develops an understanding of the definition of the term succession and its possible implications for culture and an understanding of the managerial skills necessary for the position of CEO of an organization. Therefore, the didactic objectives are (a) to understand the concepts of succession, managerial skills, and maintenance of culture; and (b) to critically analyze the processes of internal and external succession in a family business.

\section{INFORMATION SOURCES}

This teaching case was based on real facts and, for its construction, primary data were used, collected through semi-structured interviews with Tink's partners. Specifically,

\section{RESUMO}

Este caso para ensino tem por objetivo promover uma reflexão sobre o processo de sucessão da Tink, uma indústria de tintas familiar, composta por sete núcleos familiares, localizada no município de Panambi, estado do Rio Grande do Sul. Em 2018, a empresa estava no mercado há duas décadas, e Pedro, o diretor-presidente desde 2009, informou aos sócios que deixaria a gestáo em um período de dois anos. Os sócios gestores defendiam a sucessão interna e apostavam principalmente na manutenção da cultura da empresa. Já a parte dos sócios que não atuava na empresa defendia a sucessão externa, pois não identificava, na atual equipe, o perfil apto a ocupar a cadeira de Pedro. Assim, era necessário discutir sobre as possibilidades de sucessão, considerando o posicionamento divergente dos sócios. Para este caso, propóe-se que os alunos se coloquem no lugar de Pedro, a fim de propiciar-lhes um debate acerca das vantagens e desvantagens da sucessão interna e da sucessão externa para a Tink. Propóese que o caso seja utilizado em cursos de graduação e pós-graduaçáo lato sensu na área de Gestão, em disciplinas de Estratégias Organizacionais e Gestáo de Pessoas que enfoquem a sucessão em empresas familiares, as competências gerenciais e a manutenção da cultura.

Palavras-chave: sucessão; empresas familiares; competências gerenciais; manutenção da cultura; caso para ensino.

ten face-to-face interviews were conducted, via Skype and telephone calls, with an average duration of 35 minutes each. The names of the characters and the organization have been changed to preserve the confidentiality of company data and the interviewees' identities.

\section{TEACHING PLAN}

For the discussion, the suggestion is to make the case available to students in advance. At the end of these teaching notes, references are suggested, which can be used as a previous reading and support the analysis of the proposed questions. However, it is at the teacher's discretion to direct students to the reading before the analysis or elicit these readings from discussing the case in plenary. In the case's application, it is advisable to have an initial discussion in small groups and, subsequently, a plenary discussion. Finally, the teacher must end the discussion, presenting a mapping of the ideas that emerged, associated with the theoretical concepts underlying the case. Table 1 shows the distribution of the time suggested for the analysis and discussion of the case. 
Table 1. Suggestion for the distribution of time to be used in the application of the case for teaching.

\begin{tabular}{lc}
\hline \multicolumn{1}{c}{ Activities } & Duration (minutes) \\
\hline Case opening - discussion in plenary & $5-10$ \\
Initial discussion in small groups & $40-50$ \\
Debate of two major antagonistic groups & $60-70$ \\
Closing of discussions & $15-20$ \\
\hline
\end{tabular}

Note. Source: Elaborated by the authors.

\section{OPENING OF CASE DISCUSSION IN PLENARY}

At the beginning of the discussion, it is suggested that the teacher ask small groups (of three or four students) to reflect on Tink's characteristics to understand the particularities of a family business model (question 1). From this reflection, students will be more prepared for discussion in the plenary, in which the debate is proposed from two major antagonistic groups (one, in defense of internal succession, and the other, in defense of external succession). Each group must defend its position using arguments that reinforce its choice for what they consider to be the best direction for Tink.

It is expected that in the debate, the advantages and disadvantages of internal and external succession for Tink are listed (question 2), and management skills and the maintenance of culture in the succession process are discussed (questions 3 and 4). The teacher should mediate the debate, questioning the students' points and proposing that they discuss the risks in case of an unsuccessful succession. This recommendation provides an increase in tension and reinforces the importance of the students' decisions. In the end, the teacher should encourage the students to reflect, especially if the debate leads to a change in position regarding the succession.

\section{PLENARY CASE ANALYSIS}

The main questions proposed below are suggestions developed to stimulate the analysis of the case in plenary, but they can be modified at the teacher's discretion to improve their adherence to the teaching plan.

Question 1. Detail the characteristics of the company Tink.

Question 2. Assess the succession options for Tink, considering their impacts.

Question 3. Identify and analyze each of the managing partners' management skills for succession purposes at the company Tink.
Question 4. At Tink, maintaining culture was a significant factor, from the perspective of several managing partners. What can be done to ensure the maintenance of the company's culture in each succession model?

\section{ANALYSIS OF ISSUES SUPPORTED BY LITERATURE}

\section{Question 1. Detail the characteristics of the company Tink}

The first question's objective is to discuss Tink's organizational model to understand the particularities of a family business model. This initial understanding provides students with a basis for resolving subsequent questions about the succession process, management skills, and maintaining culture. To this end, transitions questions (TQ) are proposed in order to guide the students' discussion:

TQ1. What evidence does the case present that characterizes Tink's management?

Worldwide, most companies are family-controlled, whether by their founder, family members, or heirs. In other words, a family business is characterized by the union of control and management. When control is transferred to a professional, there is a separation between ownership and management (Burkart, Panunzi, \& Shleifer, 2003; La Porta, Lopez-de-Silanes, \& Shleifer, 1999). For Bernhoeft (1989), family management is characterized by the role of family members in the organization, links between origin and history, the existence of mutual trust, the influence of affective bonds, the promotion of employees associated with seniority and dedication, the manager's severe behavior, difficulties in separating the rational and the emotional, and the acceptance of power games in favor of good administration.

The literature has not yet reached a consensus on what characterizes a company as a family business 
(Pinho, Bergamaschi, \& Melo, 2006). Some factors contribute to this lack of definition. Countries do not have control and registration to identify whether the company is family-owned, and there is no universal agreement on what constitutes a family business or a professional business (Villalonga \& Amit, 2020). In this sense, some questions arise: Are first-generation companies family businesses? Are companies that belong to a single owner family businesses? Should a minimum limit on capital ownership, control, or family involvement in management be respected?

However, a family business can be conceptualized as one in which the founder or a member of his family, by blood or marriage, is a manager, individually or in a group, considering that the founder may have founded the company or a predecessor company (Anderson \& Reeb, 2003; Villalonga \& Amit, 2006). It is also evident that most family businesses present attenuators related to internal conflicts or even this problem is not identified, since the managers are owners or, at least, members of the family of the controlling owner (Villalonga, Amit, Trujillo, \& Guzmán, 2015).

Analyzing the case, it appears that the current management model of Tink, evidenced in the interviews, fits into the characteristics of a family business described by Bernhoeft (1989) and Villalonga and Amit (2006). It is observed that all managers are partners, decisions are centralized, relationships are organized hierarchically, there are paternalistic aspects, there is the influence of affective ties, and power games are accepted in favor of good coexistence in society. Trust in the CEO is also a characteristic present in family businesses, to the point that partners avoid questioning not to create conflicts. Also, Tink presents a conservative model for growth through its resources. Still, it is known that, even before being the CEO of Tink, Pedro was already its legal guardian, the creator of the business, and a majority partner. Likewise, the unification of control and management is evident since all managers are partners. Also, other characteristics of the family management model identified in the case are the difficulties in separating family relationships from professional decisions, such as, for example, hiring acquaintances without considering whether they have the ideal profile for the job.

\section{TQ2. How would you describe Tink's corporate constitution? Could it be categorized as a family business?}

Unlike traditional models, the company Tink is made up of several families, and the company model made up of more than one family is rarely mentioned by scholars (Moraes Filho, Barone, \& Pinto, 2011). Bornholdt (2005) considers this configuration a family business, stating that the family business can be composed of different family nuclei, without blood ties between families, constituting a multifamily company. The multifamily company represents the sum of skills, availability for the company, and, eventually, financial resources that can be applied to it (Gonçalves, 2000). Tink, as mentioned, presents typical characteristics of a family business and is made up of seven family nuclei, therefore being classified as a multifamily company.

\section{Question 2. Assess the succession options for Tink, considering their impacts}

The second question's objective is to discuss the advantages and disadvantages of the processes of internal versus external succession. Students need to understand the implications of the two succession processes and the risks of an unsuccessful succession to outline Tink's most recommended option. To this end, transitions questions (TQ) are proposed in order to guide the students' discussion:

TQ: What are the advantages and disadvantages of internal and external succession processesinfamily businesses?

Internal succession can be positive, as it maintains management continuity through trust. In the case under study, current managers know what happened. Thus, the whole process can be more agile (Leone, 2005). However, in decision-making, the successor may depend on the founder (Lansberg, Perrow, \& Rogolsky, 1988), and some latent conflicts in family and partner relationships can surface (Adachi, 2006).

External succession brings more freedom to decision-making, increasing the company's results (Leone, 2005; Oliveira, 2006). Professionalizing management, bringing in a professional from the market, can be a way out for a family business (Bernhoeft, 1989) because professional management can eliminate old habits from family administrations, such as conflicts overpower and the lack of preparation of current managers. Table 2 briefly presents the advantages and disadvantages of internal and external succession for family businesses. 
Table 2. Advantages and disadvantages of internal and external succession.

\begin{tabular}{llll}
\hline \multicolumn{1}{c}{ External succession } & \multicolumn{1}{c}{ Disadvantages } & \multicolumn{1}{c}{ Internal succession } \\
\hline \multicolumn{1}{c}{ Advantages } & \multicolumn{1}{c}{ Advantages } & Disadvantages \\
\hline $\begin{array}{l}\text { Eliminates old habits from family } \\
\text { administrations }\end{array}$ & $\begin{array}{l}\text { Difficulty adapting to the } \\
\text { company's culture }\end{array}$ & Maintaining the current culture & $\begin{array}{l}\text { Loss of synergy brought by the } \\
\text { market }\end{array}$ \\
$\begin{array}{l}\text { Brings market news and } \\
\text { management models }\end{array}$ & $\begin{array}{l}\text { Possible internal conflicts } \\
\text { Gradual loss of family business } \\
\text { characteristics }\end{array}$ & $\begin{array}{l}\text { Maluing the internal team } \\
\text { model }\end{array}$ & Internal power disputes \\
$\begin{array}{l}\text { Greater ease in executing } \\
\text { restructuring plans, } \\
\text { professionalizing the company }\end{array}$ & Higher risk of executive dismissal & Faster succession process & $\begin{array}{l}\text { Difficulty in firing the successor } \\
\text { executive }\end{array}$ \\
\hline
\end{tabular}

Note. Source: Elaborated by the authors, adapted from Adachi (2006), Dyer (1986), Hall and Nordqvist (2008), Lansberg, Perrow and Rogolsky (1988), Leone (2005), Lodi (1987), Oliveira (2006) and Schein (1983).

TQ: Considering the advantages and disadvantages listed, and based on the characteristics of Tink and the ideas defended by the partners about the succession process, analyze what would be the recommended option for Tink

Internal succession tends to keep the company's culture rooted, with the vision of a large family, with managers already experienced in their roles and followers of the current management model (Hall \& Nordqvist, 2008), which pleases part of the partners, mainly managing partners and their families. However, this option can maintain management vices and limitations in the market because there is no team manager aware of the sector's practices coming from competing organizations. Besides, the inexperience of the possible successors to the position was made explicit when their profiles were analyzed and given their attitude of not presenting themselves as candidates.

External succession, on the other hand, can bring objectivity and rationality to the family business (Schein, 1983), direct new leadership patterns, and create new strategic positions, with a focus on growth and expansion, in addition to mitigating possible family conflicts (Dyer, 1986). This option appeals to the partners that do not identify a possible successor among the managers, who believe that conflicts may arise between families and that the knowledge and experience of an external professional would make Tink more competitive.

Regardless of the company's decision, internal or external succession, it is necessary to plan this process and encourage the partners to take a stand.
Question 3. Identify and analyze the management skills of each of the managing partners, for succession purposes at the company Tink

The third question's objective is for the students to list the competencies of each of the three managing partners who could succeed Pedro, identified during the teaching case, to determine whether they have the necessary competencies for the position of chief executive officer. It is also proposed that the teacher groups the skills listed by the students through the categorization of Fleury and Fleury (2004), which classifies them as technical-professional, business, and social. To this end, transitions questions (TQ) are proposed in order to guide the students' discussion:

TQ: What are the technical-professional, business, and social skills identified in each of the managing partners in Tink's succession process?

Managerial competencies are linked to organizations' knowledge and skills due to their structures, processes, guidelines, and objectives outlined to be achieved through executive action (Cassol, Cintra, Ruas, \& Bassani, 2016). Thus, for a good performance in the organization, some competencies are relevant, in particular: (a) technicalprofessional competences, which refer to those associated with a particular occupation or activity; (b) business skills, which deal with those related to the business as a whole, contemplating the relationships with stakeholders - customers, suppliers, and competitors - as well as the social and political aspects of the environment in which they operate; and (c) social skills, which are those used for 
interpersonal interaction, both in general communication and in business negotiations (Fleury \& Fleury, 2004).

In this sense, the need to assess the profile of Tink's managing partners is demonstrated. In this sense, it appears that Jorge has technical and professional skills, has skills in the accounting and financial area, technical profile, and characteristics of a good accountant. Concerning business skills, he understands the organization's objectives and processes since he and Fausto were responsible for the company's operation for some years. However, Tink went through adjustments and, in the last years, Jorge was restricted to the financial and administrative areas. Jorge had no experience in other companies in the segment. Regarding social skills, the case narrative presents his difficulty in interpersonal relationships.

On the other hand, Fausto needs to improve his technical-professional skills, as some managers identify him as having difficulty doing profitable business. As for business competence, as mentioned earlier, Fausto was responsible for its operation for some years. Thus, like Jorge, he knows many processes. However, his role has been restricted to sales since he lacks experience in other companies in the segment. On social skills, according to the data presented in the case, he has good personal relationships with the team.

Finally, Jean has the necessary knowledge to exercise his occupation. However, he still needs to improve his technical-professional skills since, as he exercises the position of manager of the production area, he needs to deal with unforeseen circumstances and to have strategies for the lack of inputs or labor, for example. Regarding his managerial skills, he has worked in some positions before becoming a manager. However, his understanding of the business is more restricted since he has not had the opportunity to work in other sectors and has no previous experience in the labor market. About social competence, Jean's relationship with his team is not mentioned here.

\section{TQ: Considering the skills identified,} analyze the profile of the managing partners for succession at Tink

Analyzing the profile of the managing partners of Tink regarding their management skills, Jorge, Fausto, and Jean do not have all the skills necessary for the management of a company. Thus, if one of them were to replace Pedro in the succession process, it would be necessary to enhance his strengths and develop his weaknesses. Among the weaknesses, it is worth mentioning that the lack of business competence stood out for the three, as the managing partners would need to know the company as a whole.
Question 4. At Tink, maintaining culture was a significant factor, from the perspective of several partners. What can be done to ensure the maintenance of the company's culture in each succession model?

The fourth question's objective is to discuss whether maintaining culture is a limiting factor for external succession at Tink, considering its family business model and its particularities, and analyzing how to ensure the maintenance of the company's culture in each of the succession models. To this end, transitions questions (TQ) are proposed in order to guide the students' discussion:

\section{TQ: Is maintaining culture a determining factor for succession in family businesses like Tink?}

In any change process in a family business, the culture will be a determining factor, bringing both positive and negative influences (Oliveira \& Papa, 2009). In the succession process, with new power relations, new access to resources, new institutional structure, and new practices, cultural shocks will be felt, and the successor and other members involved will need to recognize the fact and act effectively at that moment of tension (Muzzio, 2013). Tink's partners considered organizational culture a critical condition for its succession process and were concerned about its conservation.

According to the succession model adopted internal or external - , specific strategies will be used to ensure the maintenance of the company's culture. As listed in the case narrative, the partners recognize that an external member could have difficulty adapting to the family culture experienced in the company. An internal member, for sharing the culture, would not suffer the same shocks. Therefore, in an internal succession, the maintenance of the culture will occur through the continuity of the current management, without making extreme changes. As for external succession, the culture's maintenance will occur by incorporating the company's cultural aspects by the new manager.

After all, in the external succession, a professionalization process is sought, making it necessary to change the company. Cultural conflicts do not occur along these lines, and it is recommended that such changes be implemented gradually (López, Ortiz, Quinteros, \& Moreno, 2013).

All new professional managers tend to establish new practices and a new model, which aligns with the emerging organizational reality (Muzzio, 2013). Thus, to ensure the effectiveness of practices, this process must be well planned. 
In Tink's case, because the company is made up of seven family nuclei, communication throughout the process will be essential so that there are no differences.

TQ: What is the relevance of cultural competence for Tink, if you choose the external succession process?

Cultural competence is a requirement for succession, as the manager will find a solid and rooted culture (Muzzio, 2013). Cultural competence is associated with the individual's condition of knowledge, skills, and attitudes that allow him to act in intercultural contexts (Egan \& Bendick, 2008). Therefore, in addition to managerial skills, it is necessary to analyze cultural competence to define a successor for a family

\section{REFERENCES}

Adachi, P. P. (2006). Família S. A.: Gestão de empresa familiar e solução de conflitos. São Paulo: Atlas.

Anderson, R. C., \& Reeb, D. M. (2003). Founding-family ownership and firm performance: Evidence from the S\&P 500. The Journal of Finance, 58(3), 1301-1328. https://doi.org/10.1111/1540-6261.00567

Bernhoeft, R. (1989). Empresa familiar: Sucessão profissionalizada ou sobrevivência comprometida (1 ed.). Sáo Paulo: Nobel.

Bornholdt, W. (2005). Governança na empresa familiar: Implementação e prática. Porto Alegre: Bookman.

Burkart, M., Panunzi, F., \& Shleifer, A. (2003). Family firms. The Journal of Finance, 58(5), 2167-2201. https://doi.org/10.1111/1540-6261.00601

Cassol, A., Cintra, R. F., Ruas, R. L., \& Bassani, D. (2016). Evidenciação das competências gerenciais e a influência na atuação estratégica das micro e pequenas empresas de Santa Catarina. Revista da Micro e Pequena Empresa, 10(3), 49-68. Retrieved from http://www.cc.faccamp.br/ ojs-2.4.8-2/index.php/RMPE/article/view/850 business, as is Tink's case. Regarding external succession, culture becomes a limiting factor as the future successor tries to impose his culture in opposition to the company's culture or if he does not adapt to the existing culture. If the future manager has the necessary skills to work in intercultural contexts, there will be no conflicts.

\section{CLOSING OF THE DISCUSSION}

At the end of the case, the two groups are to design a management plan for Tink based on the succession defended by them. In this plan, students can list possible conflicts in the implementation and define how they will mitigate these impasses.
Dyer, W. G., Jr. (1986). Cultural change in family firms: Anticipating and managing business and family transition. San Francisco: Jossey-Bass.

Egan, M. L., \& Bendick, M. (2008). Combining multicultural management and diversity into one course on cultural competence. Academy of Management Learning \& Education, 7(3), 387-393. https://doi.org/10.5465/amle.2008.34251675

Fleury, A., \& Fleury, M. T. L. (2004). Estratégias empresariais e formaçẫo de competências: Um quebra-cabę̧a caleidoscópico da indústria brasileira (3 ed.). São Paulo: Atlas.

Gonçalves, J. (2000). As empresas familiares no Brasil. Revista de Administração de Empresas, 40(1), 7-12. https://doi.org/10.1590/S0034-75902000000100012

Hall, A., \& Nordqvist, M. (2008). Professional management in family businesses: Toward an extended understanding. Family Business Review, 21(1), 51-69. https://doi.org/10.1111/j.1741-6248.2007.00109.x 
Lansberg, I., Perrow, E. L., \& Rogolsky, S. (1988). Editors' notes. Family Business Review, 1(1), 1-8. https://doi.org/10.1111/j.1741-6248.1988.00001.x

La Porta, R., Lopez-de-Silanes, F., \& Shleifer, A. (1999). Corporate ownership around the world. The Journal of Finance, 54(2), 471-517. https://doi.org/10.1111/0022-1082.00115

Leone, N. (2005). Sucessão na empresa familiar: preparando as mudanças para garantir sobrevivência no mercado globalizado. Sáo Paulo: Atlas.

Lodi, J. B. (1987). Sucessão e conflito na empresa familiar. São Paulo: Pioneira.

López, A. V., Ortiz, M. V. F., Quinteros, M. M. S., \& Moreno, E. A. C. (2013). La profesionalización como factor de competitividad: Un análisis de las empresas familiares del sector industrial, en Tijuana, B.C., México. Revista Internacional Administración \& Finanzas, 6(1), 23-38. Retrieved from https://www.theibfr.com/wpfb-file/riaf-v6n1-2013-2-pdf/

Moraes Filho, A. C. T. de, Barone, F. M., \& Pinto, M. de O. (2011). A produçáo científica em empresas familiares: Um enfoque conceitual. Revista Brasileira de Administração Pública, 45(6), 1971-1991. Retrieved from http://bibliotecadigital. fgv.br/ojs/index.php/rap/article/view/7068

Muzzio, H. A. (2013). A consolidação da profissionalização da empresa familiar e o legado do fundador: Concepçóes teóricas e implicaçóes práticas. Teoria e Prática em Administração, 3(2), 27-43. Retrieved from http://www. periodicos.ufpb.br/ojs/index.php/tpa/article/view/14076
Oliveira, D. P. R. (2006). Empresa familiar: Como fortalecer o empreendimento e otimizar o processo sucessório. (2 ed.). São Paulo: Atlas.

Oliveira, A. A., \& Papa, A. C. (2009). A influência da cultura organizacional no processo de profissionalização da gestáo em uma empresa familiar. Revista de Administração da UFSM, 2(3), 385-398. Retrieved from https://periodicos. ufsm.br/reaufsm/article/view/1636/0

Pinho, F. F. de, Bergamaschi, L. S., \& Melo, J. S. C. (2006, September). Relaçóes de gênero: Uma categoria introduzida ao modelo tridimensional de desenvolvimento de empresa familiar. Proceedings of the Encontro Nacional da Associação Nacional de Pós-Graduação e Pesquisa em Administração, Salvador, BA, Brazil, 30. Retrieved from http://www.anpad.org.br/ diversos/down zips/10/enanpad2006-eora-1348.pdf

Schein, E. H. (1983). The role of the founder in creating organizational culture. Organizational Dynamics, 12(1), 13-28. https://doi.org/10.1016/0090-2616(83)90023-2

Villalonga, B., Amit, R., Trujillo, M.-A., \& Guzmán, A. (2015). Governance of family firms. Annual Review of Financial Economics, 7, 635-654. https://doi.org/10.1146/annurev-financial-110613-034357

Villalonga, B., \& Amit, R. (2006). How do family ownership, control and management affect firm value? Journal of Financial Economics, 80(2), 385-417. https://doi.org/10.1016/j.jfineco.2004.12.005

Villalonga, B., \& Amit, R. (2020). Family ownership. Oxford Review of Economic Policy, 36(2), 241-257. https://doi.org/10.1093/oxrep/graa007 


\section{Authorship}

\section{Eleandra Maria Prigol Meneghini*}

Universidade do Vale do Itajaí, Programa de Pós-Graduação em Administração

Rua Uruguai, no 458, Centro, 88302-202, Itajaí, SC, Brazil

E-mail address: eleandra.meneghini@gmail.com

(1) https://orcid.org/0000-0002-2961-882X

\section{Ana Paula Pereira dos Passos}

Universidade do Vale do Itajaí, Programa de Pós-Graduação em Administração

Rua Uruguai, no 458, Centro, 88302-202, Itajaí, SC, Brazil

E-mail address: passosapp@gmail.com

(1) https://orcid.org/0000-0003-0684-8582

\section{Sidnei Vieira Marinho}

Universidade do Vale do Itajaí, Programa de Pós-Graduação em Administração

Rua Uruguai, no 458, Centro, 88302-202, Itajaí, SC, Brazil

E-mail address: sidnei@univali.br

(1) https://orcid.org/0000-0003-0396-5898

\section{Anete Alberton}

Universidade do Vale do Itajaí, Programa de Pós-Graduação em Administração

Rua Uruguai, no 458, Centro, 88302-202, Itajaí, SC, Brazil

E-mail address: anete@univali.br

(1) https://orcid.org/0000-0002-6477-0122

* Corresponding Author

\section{Funding}

The authors would like to thank the Coordination for the Improvement of Higher Education Personnel (CAPES) for their financial support.

\section{Conflict of Interests}

The authors have stated that there is no conflict of interest.

\section{Authors' Contributions}

$1^{\text {st }}$ author: conceptualization (lead); investigation (equal); data curation (equal); writing - original draft (equal); project administration (lead); validation (equal).

$2^{\text {nd }}$ author: conceptualization (equal); investigation (equal); data curation (equal); writing - original draft (equal); validation (equal).

$3^{\text {rd }}$ author: conceptualization (equal); investigation (supporting); writing - original draft (equal); validation (equal).

$4^{\text {th }}$ author: conceptualization (equal); investigation (supporting); writing - original draft (equal); validation (equal).

\section{Copyrights}

RAC owns the copyright to this content.

\section{Plagiarism Check}

The RAC maintains the practice of submitting all documents approved for publication to the plagiarism check, using specific tools, e.g.: iThenticate.

\section{Peer Review Method}

This content was evaluated using the double-blind peer review process. The disclosure of the reviewers' information on the first page, as well as the Peer Review Report, is made only after concluding the evaluation process, and with the voluntary consent of the respective reviewers and authors.

\section{Data Availability}

RAC encourages data sharing but, in compliance with ethical principles, it does not demand the disclosure of any means of identifying research subjects, preserving the privacy of research subjects. The practice of open data is to enable the reproducibility of results, and to ensure the unrestricted transparency of the results of the published research, without requiring the identity of research subjects. 